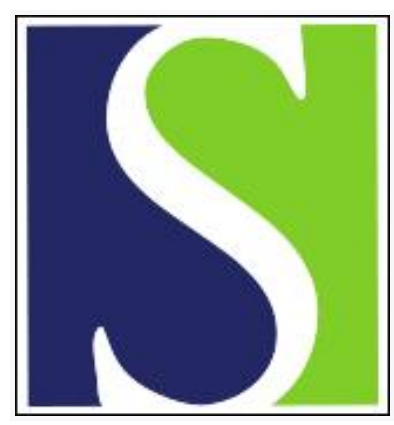

Scand J Work Environ Health 1986;12(6):552-560

https://doi.org/10.5271/sjweh.2101

Issue date: Dec 1986

Mortality among production workers in pulp and paper mills.

by Robinson CF, Waxweiler RJ, Fowler DP

This article in PubMed: www.ncbi.nlm.nih.gov/pubmed/3823804

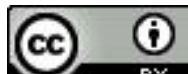




\title{
Mortality among production workers in pulp and paper mills
}

\author{
by Cynthia F Robinson, PhD, ${ }^{1}$ Richard J Waxweiler, PhD, ${ }^{1}$ Douglas P Fowler, $\mathrm{PhD}^{2}$
}

\begin{abstract}
ROBINSON CF, WAXWEILER RJ, FOWLER DP. Mortality among production workers in pulp and paper mills. Scand J Work Environ Health 12 (1986) 552-560. A cohort of 3572 pulp and paper mill workers employed for at least one year between 1945 and 1955 was followed through 31 March 1977. Vital status was determined for $99 \%$ of the cohort. The 915 deaths observed were $79 \%$ of the number expected on the basis of comparable United States mortality rates. Statistically nonsignificant excesses of deaths due to lymphosarcoma and reticulosarcoma and to stomach cancer were observed. These findings tend to corroborate reports based on state vital statistics, and preliminary case-referent and populationbased studies of workers in the pulp or paper industries. No deaths due to nasal cancer were observed, but only 0.6 were expected. When process-specific analyses were conducted, the excess risk of lymphosarcoma and reticulosarcoma was increased only for men who worked in sulfate mills. The excess risk of stomach cancer was limited to men who worked in sulfite mills. Process-specific standardized mortality ratios for these causes were highest after 20 years since first employment in the mills.
\end{abstract}

Key terms: formaldehyde, lymphosarcoma, occupational health, pentachlorophenol, stomach cancer, wood dust.

Of approximately 600000 people currently employed in the paper and allied products industry in the United States (US), 155000 are production workers in pulp, paper, or paperboard mills (28). The industry has two distinct process stages: wood pulping and paper making. Both may be contained within one mill or may take place in separate locations, depending upon supplies of wood and water. This large industry may involve occupational exposures to sulfur compounds, chlorine, chlorine dioxide, lime, caustic soda, soda ash, alum, pigments, metallic dusts, paper and other dusts, and various other potentially toxic chemicals in addition to the suspect human carcinogen wood dust (14) and the known animal carcinogen formaldehyde (15).

Suspicions that workers in the pulp and paper industry might be at increased risk for several site-specific malignancies, particularly of the lymphatic and hematopoietic system, were initially raised by analyses using state vital statistics data $(20,21,22)$. In addition, in US counties with pulp or paper manufacturing industry, there tended to be elevated rates of oral (2) and lung cancer $(1,12,19)$ among males (table 1).

Few detailed analytic studies of pulp and paper mill workers have been published. In a large multitumorsite case-referent study, Decoufle et al (21) found that men who had worked as operatives in the paper industry for five years or more had an increased relative risk for lymphoma, multiple myeloma, leukemia, and malignancies of the buccal cavity, pharynx, larynx, stomach, prostate, kidney, colon, rectum, and lung.

\footnotetext{
1 National Institute for Occupational Safety and Health, Cincinnati, Ohio, United States.

2 SRI International, Menlo Park, California, United States.
}

Reprint requests to: Dr CF Robinson, National Institute for Occupational Safety and Health, DSDTT/DBBS, Mail Stop C-32, 4676 Columbia Parkway, Cincinnati, Ohio 45226, USA.
However, unevaluated hospital referral patterns may have contributed unknown biases.

In the only published retrospective cohort mortality study of workers in a pulp and paper mill, Ferris et al (6) followed for 10 years a cohort of 271 pulp and paper mill workers identified as actively working in the mill in 1963. Although only 33 deaths occurred among these workers by 1973, the 33 deceased paper and pulp mill workers were reported to have an overall standardized mortality ratio of 126 . No cause-specific expected deaths were computed, the period of observation was short, and there was a substantial lack of statistical power.

Because of these associations between various malignancies and pulp and paper mill employment, we conducted a retrospective cohort mortality study of men employed in five pulp and paper mills located in the northwestern part of the United States. Our study was designed to evaluate the chronic health effects of employment in this industry and to test the hypotheses of increased mortality due to malignancies of the buccal cavity, pharynx, stomach, intestine/rectum, larynx, lung, prostate, bladder, kidney, and the hematopoietic and lymphatic systems (table 1), as well as that due to coronary heart disease and diseases of the blood-forming organs $(20,21)$.

\section{Description of industry}

Two chemical processes, sulfate (or Kraft) and sulfite, and one mechanical process, groundwood, were dominant in the pulp industry in the United States during the study period. In 1950 approximately $25 \%$ of the 260 active US woodpulp mills used the sulfate process, $23 \%$ used the sulfite process, and $35 \%$ were 
Table 1. Previously reported associations ${ }^{a}$ between paper-related industries and site-specific cancers.

\begin{tabular}{|c|c|c|}
\hline Type of cancer & Pulp and paper & Sawyers, sawmills or logging \\
\hline Buccal and pharynx & Blot \& Fraumeni (2), Decoufle et al (4) & . \\
\hline Stomach & $\begin{array}{l}\text { Decoufle et al (4), Milham (21), Registrar } \\
\text { General }(24,25,26)\end{array}$ & $\begin{array}{l}\text { Guralnick (10), Milham }(20,21) \text {, } \\
\text { Registrar General (24) }\end{array}$ \\
\hline Intestines, rectum & Decoufle et al (4), Milham $(20,21)$ & Milham $(20)$ \\
\hline Larynx & Decoufle et al $(4)$, Milham $(20,21)$ & Milham (21) \\
\hline Lung & $\begin{array}{l}\text { Blot \& Fraumeni (1), Decoufle et al (4), } \\
\text { Harrington et al (12), Menck \& Henderson (19), } \\
\text { Milham (21) }\end{array}$ & . \\
\hline Prostate & $\begin{array}{l}\text { Gallagher \& Threlfall (8), McDonald (18), } \\
\text { Milham }(20,21) \text {, Registrar General }(23)\end{array}$ & Guralnick (10), Milham (20) \\
\hline Bladder & Milham (20) & Milham (20), Registrar General (26) \\
\hline Kidney & Decoufle et al $(4)$, Milham $(20,21)$ & Milham $(20,21)$ \\
\hline $\begin{array}{l}\text { Lymphoma, lympho- } \\
\text { sarcoma }\end{array}$ & $\begin{array}{l}\text { Decoufle et al (4), Gallagher \& Threlfall (8), } \\
\text { Milham }(20,21) \text {, Registrar General }(23)\end{array}$ & Milham (20) \\
\hline Hodgkin's disease & Milham $(20,21)$, Milham \& Hesser $(22)$ & . \\
\hline Multiple myeloma & Decoufle et al $(4)$, Milham $(20,21)$ & . \\
\hline Leukemia & Decoufle et al (4), Milham $(20,21)$ & Milham $(20,21)$, Registrar General $(25,26)$ \\
\hline
\end{tabular}

a Relative risk greater than 1.2 or statistically significant.

groundwood mills. The remaining $17 \%$ used various processes, principally soda and semichemical. In contrast, by 1974 , the 349 active US mills were comprised of $11 \%$ sulfite and $20 \%$ groundwood processes, while the sulfate process had increased in use to $34 \%$ of the total. The remaining $35 \%$ was principally composed of the newer defibrated process and semichemical mills, with very few soda and chemimechanical process mills (7). Of the total US pulp production today, over $60 \%$ is produced in sulfate mills, with less than $10 \%$ accounted for by sulfite mills. Due to the changing technology, it was decided to study workers employed in the two major processes, ie, sulfate and sulfite.

The sulfate process, which is alkaline-based, depends mainly on pine wood (in the southern part of the United States) or fir (in the northwest mills studied). The acid-based sulfite process most commonly uses low resin woods such as spruce or hemlock, which contain hydroxyphenolic compounds. Almost any softwood can be used in the groundwood process; one of the sulfite mills in our study also ran a groundwood process which used both fir and hemlock (18).

Occupational exposures may arise at any stage in the process from preparation of the raw wood through the production of the final paper or pulp product (table 2). Wood preparation does not differ substantially for the several processes, but there can be significant differences in exposures in subsequent process steps, particularly in two areas, ie, in cooking liquor production and in pulp production, washing, bleaching and recovery, which together convert the wood fibers into cellulose fibers, ready for subsequent processing into paper of various grades or for direct sale as pulp.

Paper making often takes place in the same plant which produces the pulp, as was true for four of the five mills studied. The pulp is mixed with water and
Table 2. Pulp and paper mill exposures.

\begin{tabular}{|c|c|}
\hline Production area or job & $\begin{array}{l}\text { Potential exposures during } \\
\text { study period }\end{array}$ \\
\hline $\begin{array}{l}\text { Raw wood preparation, } \\
\text { ie, debarking and } \\
\text { chipping }\end{array}$ & $\begin{array}{l}\text { Wood volatiles, wood dust, } \\
\text { (Douglas fir, hemlock), spores } \\
\text { and fungi }\end{array}$ \\
\hline \multirow[t]{2}{*}{$\begin{array}{l}\text { Production of cooking } \\
\text { liquor }\end{array}$} & $\begin{array}{l}\text { Sulfate: ammonia, hydrogen sul- } \\
\text { fide, sulfur dioxide, mercaptans, } \\
\text { chromates (as contaminants) }\end{array}$ \\
\hline & $\begin{array}{l}\text { Sulfite: sulfur, sulfur dioxide, } \\
\text { calcium carbonate, zinc, sulfuric } \\
\text { acid, lead fumes, asbestos, } \\
\text { sulfurous acid }\end{array}$ \\
\hline \multirow[t]{2}{*}{$\begin{array}{l}\text { Pulp production, } \\
\text { cooking }\end{array}$} & $\begin{array}{l}\text { Sulfate: lime, magnesium, wood } \\
\text { volatiles }\end{array}$ \\
\hline & $\begin{array}{l}\text { Sulfite: pigments, dyes, wood } \\
\text { volatiles } \\
\text { Groundwood: wood volatiles }\end{array}$ \\
\hline $\begin{array}{l}\text { Pulp bleaching and } \\
\text { bleach plant }\end{array}$ & $\begin{array}{l}\text { Chlorine compounds, boron com- } \\
\text { pounds, caustic neoabietic acids }\end{array}$ \\
\hline $\begin{array}{l}\text { Wet pulp paper } \\
\text { additives }\end{array}$ & $\begin{array}{l}\text { Talc, clays, titanium dioxide, } \\
\text { urea and melamine formaldehyde, } \\
\text { pigments and dyes }\end{array}$ \\
\hline $\begin{array}{l}\text { Bleaching and } \\
\text { additives }\end{array}$ & $\begin{array}{l}\text { Same as for pulp bleaching, } \\
\text { bleach plant and wet pulp paper } \\
\text { additives }\end{array}$ \\
\hline $\begin{array}{l}\text { Paper rolling, sizing, } \\
\text { dying, drying, glazing, } \\
\text { coating }\end{array}$ & $\begin{array}{l}\text { Urea and melamine formaldehyde, } \\
\text { paper dust, coating and pigment } \\
\text { dusts (aniline dye in the ground- } \\
\text { wood process plant) }\end{array}$ \\
\hline Maintenance & General plant exposures \\
\hline $\begin{array}{l}\text { Unknown jobs, power } \\
\text { and utility }\end{array}$ & General plant exposures \\
\hline Unexposed jobs & No significant exposures \\
\hline
\end{tabular}

additives (if used) such as sizing agents (eg, formaldehyde compounds), fillers, and dyes. This slurry is formed into sheets and dried; then it may be coated, glazed, printed, and otherwise treated to complete the paper-making process. 


\section{Subjects and methods}

All 37 pulp and paper mills in the states of Washington, Oregon and California that were thought to have been in operation prior to 1950 were surveyed. Five pulp and paper mills were selected for study on the basis of the age of the mill, the completeness of the personnel records, and the type of process used by the mill. Of the five pulp and paper mills selected, three produced Kraft sulfate or sulfate pulp (which are essentially the same process) and two produced sulfite pulp. One of the two sulfite pulp mills also used the groundwood process, which is purely mechanical and involves no chemical treatment of the pulp. All five mills began pulp operations between 1918 and 1930 . The end products of the study mills were newsprint, purified chemical cellulose, bleached and unbleached pulp, paper, board and boxboard. A different bleach process was used by each of the four mills which used bleach.

Before the pulp and paper mills were selected, the study cohort was defined to include only white males who worked at least one year between 1945-1955 inclusive. These criteria allowed the investigation to focus on persons with a minimum latency and whose followup would be facilitated due to their occupational stability and their having worked after World War II. Salaried office workers, females, and nonwhite males were excluded from the study due to their minimal exposures or small numbers. Employment records of the remaining men were microfilmed. The demographic data and the daily detailed work histories of each worker, including departments, job titles and dates, including layoffs, were coded for the computer from these records.

The 3572 pulp and paper workers who met the study cohort criteria were followed from their last date of employment through 31 March 1977 (table 3). Vital status for $99 \%$ of the study cohort was determined through records maintained by the Social Security Administration, the Internal Revenue Service, the state bureaus of motor vehicles, telephone directories, and other sources. Death certificates were obtained for $99 \%$ of those deceased. Underlying causes of death were interpreted and coded by a nosologist according to the revision of the International Classification of Diseases (ICD) in effect at the time of death. Indi-

Table 3. Vital status of paper and pulp mill workers in the northwest section of the United States as of 31 March 1977.

\begin{tabular}{lrr}
\hline Vital status & Number & Percent \\
\hline Alive & 2608 & 73 \\
Deceased & 915 & 25 \\
With death certificate & 903 & 99 \\
Without death certificate & 12 & 1 \\
Lost to follow-up & 49 & 1 \\
\hline Total workers & 3572 & 100 \\
(Total person-years 90 961) & & \\
\hline
\end{tabular}

viduals with unknown vital status were assumed to be alive as of 31 March 1977. The 12 deceased individuals for whom no death certificate was available were assumed to be deceased, cause unknown.

A modified life-table technique (31) was used to obtain person-years at risk of dying by race and sex in five-year calendar-time periods, five-year age groups, five-year duration of employment periods, and fiveyear latency (time since first employment at the plant) periods. Person-years were multiplied by the appropriate US mortality rates to obtain the expected number of deaths. ${ }^{3}$ Since the cohort was limited to white male production employees who had at least one year of employment between 1945 and 1955, person-years at risk began either at one year after first date of employment or on 1 January 1946, whichever came later.

Workers were included in a process subcohort analysis if they worked for one year or more in the appropriate process category. The sulfite process subcohort consisted of 1779 men, and the sulfate subcohort of 1796 men. It was possible for a person to be included in more than one process subcohort if he worked in more than one study mill; however only a few persons had worked longer than one year in each of the processes studied.

Because of the widespread interest in the health effects of formaldehyde, an additional subcohort of 1262 men was examined separately. These men had worked $1 \mathrm{~d}$ or more in the areas of the mills believed to have had formaldehyde exposures (table 2). These areas were the paper-making portion of the mills, where urea and melamine formaldehyde resins were used (15). These resins were used in some of the sizing agents and pigments added to the slurry. They were also contained in some of the coatings applied to finished paper.

The observed numbers of deaths in the study cohort and subcohorts were compared with the numbers expected as derived from sex-, age-, race-; calendar-time-, and cause-specific US mortality rates. SMR values were calculated by dividing the number of observed deaths by the number of expected deaths and multiplying by 100. The SMR values were not calculated when the observed and expected numbers of deaths were both less than three. On the basis of our literature review, we developed a priori hypotheses for excess risks of death due to the malignancies listed in table 1 , coronary heart disease and diseases of the blood-forming organs. Thus we decided to use one-sided testing of these causes of death at the 0.05 alpha level. We also wanted estimates of upper limits of risk. Consequently, we calculated two-sided $90 \%$ confidence interval $(90 \% \mathrm{CI})$ values for the SMR values. An evaluation of the lower limit of these is equivalent to evaluation of the one-sided $p=0.05$ test of excess risk. For consistency, similar

\footnotetext{
3 Because appropriate comparison rates for lymphosarcoma and reticulosarcoma were not available before 1950, the rates from 1950-1954 were used for 1946-1949.
} 
confidence intervals are presented for all SMR values in the paper. The Fisher exact method was used to calculate the intervals if the observed deaths were less than eight, and an approximate method was used if the observed number of deaths was eight or more (27).

\section{Results}

For the entire cohort (table 3), 90961 person-years of observation were accrued. A statistically significant deficit of deaths was observed, 915 versus 1150.3 expected (SMR 79) (table 4).

Mortality due to circulatory system disease (SMR 81) and all malignant neoplasms (SMR 76) was also statistically significantly below that expected. The SMR values for the following five site-specific malignancies were nonsignificantly elevated: stomach cancer (17 observed, 13.8 expected, SMR 123), prostate cancer (17 observed, 14.8 expected, SMR 115), kidney cancer (6 observed, 5.2 expected, SMR 115), bladder cancer (8 observed, 6.9 expected, SMR 116), and lymphosarcoma and reticulosarcoma (10 observed, 5.9 expected, SMR 169). All intestinal malignancies were of the colon; none were of the small intestine. Of the 10 deaths in the lymphosarcoma and reticulosarcoma category, nine $(90 \%)$ were due to lymphosarcoma, as opposed to $61 \%$ observed in the US population for 1970 (29). There was a slight excess of deaths due to diseases of the blood-forming organs ( 5 observed, 3.0 expected, SMR 167). No deaths due to nasal cancers were found. In addition, a careful review of all 903 death certificates revealed no mention of sinonasal cancer as a contributory cause of death or other significant condition.

A detailed examination of the work histories of the 10 lymphosarcoma and reticulosarcoma cases revealed that four of the men worked in pulp production, two worked in raw wood preparation, two worked in maintenance, and two worked in paper-making areas. The bimodal age distribution of deaths was not unusual.

Only causes of death with elevated SMR values or those causes of death which were of interest because an excess risk had been observed in previous studies are presented in tables 6 and 7 for the process subcohorts. Among the subcohort of sulfite/groundwood process workers (table 6), significantly fewer deaths occurred than were expected, resulting in an SMR of 86. The SMR values were elevated, but were not statistically significant, for two site-specific malignancies, ie, stomach cancer (11 observed, 7.4 expected, SMR 149) and kidney cancer ( 4 observed, 2.7 expected, SMR 148). The few deaths due to diseases of the blood and blood-forming organs were more than expected ( 3 observed, 1.6 expected).

There were 392 deaths among the subcohort of men employed in pulp and paper mills (table 7) which used Kraft or sulfate pulping processes, whereas 544.1 deaths were expected, resulting in a significantly decreased SMR of 72. The SMR for all malignant neoplasms was also $72 \%$ of that expected. However, there was a twofold excess (90\% CI 90-408) due to lym-

Table 4. Cause-specific deaths among white males employed in five northwest pulp and paper mills.

\begin{tabular}{|c|c|c|c|c|}
\hline Cause of death ${ }^{a}$ & $\begin{array}{l}\text { Observed } \\
\text { deaths }\end{array}$ & $\begin{array}{l}\text { Expected } \\
\text { deaths }\end{array}$ & $\begin{array}{l}\text { Standardized } \\
\text { mortality } \\
\text { ratio }\end{array}$ & $\begin{array}{l}90 \% \\
\text { confidence } \\
\text { limits }\end{array}$ \\
\hline Malignant neoplasms $(140-205)$ & 160 & 211.5 & 76 & $66-86$ \\
\hline $\begin{array}{l}\text { Buccal cavity and pharynx }(140-148) \\
\text { Digestive system }(150-159)\end{array}$ & $\begin{array}{r}1 \\
42\end{array}$ & $\begin{array}{r}7.0 \\
64.9\end{array}$ & $\begin{array}{l}14 \\
65\end{array}$ & $\begin{array}{r}0-68 \\
49-84\end{array}$ \\
\hline $\begin{array}{l}\text { Stomach }(151) \\
\text { Intestines }(152,153) \\
\text { Pancreas (157) }\end{array}$ & $\begin{array}{r}17 \\
7 \\
4\end{array}$ & $\begin{array}{l}13.8 \\
19.7 \\
11.9\end{array}$ & $\begin{array}{r}123 \\
35 \\
34\end{array}$ & $\begin{array}{l}78-185 \\
17-67 \\
11-77\end{array}$ \\
\hline $\begin{array}{l}\text { Nasal }(160) \\
\text { Larynx }(161) \\
\text { Lung }(162-163) \\
\text { Prostate }(177) \\
\text { Kidney }(180) \\
\text { Bladder (181) } \\
\text { Brain (193) } \\
\text { Lymphosarcoma and reticulosarcoma (200) } \\
\text { Hodgkin's disease (201) } \\
\text { Leukemia (204) } \\
\text { Other lymphatic (202, 203-205) }\end{array}$ & $\begin{array}{r}- \\
3 \\
50 \\
17 \\
6 \\
8 \\
4 \\
10 \\
1 \\
4 \\
2\end{array}$ & $\begin{array}{r}0.6 \\
3.3 \\
62.1 \\
14.8 \\
5.2 \\
6.9 \\
6.3 \\
5.9 \\
2.7 \\
8.7 \\
3.0\end{array}$ & $\begin{array}{r}91 \\
81 \\
115 \\
115 \\
116 \\
63 \\
169 \\
46\end{array}$ & $\begin{array}{l}25-235 \\
63-102 \\
73-172 \\
50-228 \\
58-209 \\
21-145 \\
92-287 \\
22-145 \\
\end{array}$ \\
\hline $\begin{array}{l}\text { Diseases of the blood-forming organs }(290-299) \\
\text { Vascular lesions of the central nervous system } \\
\text { (330-334) } \\
\text { Diseases of the circulatory system }(400-468) \\
\text { Nonmalignant respiratory disease }(470-527) \\
\text { Accidents }(800-962) \\
\text { Residual causes, unknown }\end{array}$ & $\begin{array}{r}5 \\
72 \\
432 \\
52 \\
72 \\
122\end{array}$ & $\begin{array}{r}3.0 \\
85.1 \\
532.1 \\
62.7 \\
73.6 \\
182.3\end{array}$ & $\begin{array}{l}167 \\
85 \\
81 \\
83 \\
98 \\
67\end{array}$ & $\begin{array}{l}66-350 \\
69-103 \\
75-88 \\
65-105 \\
80-119 \\
57-78\end{array}$ \\
\hline Total & 915 & 1150.3 & 79 & $75-84$ \\
\hline
\end{tabular}

a Code of the International Classification of Diseases, seventh revision, in parentheses. 
phosarcoma and reticulosarcoma (6 observed, 2.9 expected, SMR 207). Only lymphosarcoma was found among the sulfate workers; no reticulosarcoma deaths occurred. A slight excess mortality occurred due to cancer of the prostate ( 8 observed, 6.7 expected, SMR 119) and cancer of the bladder (4 observed, 3.2 expected, SMR 125).

Mortality due to lymphosarcoma among the sulfate process workers and mortality due to stomach cancer among the sulfite process workers, as well as mortality due to prostate and urinary tract cancer among the

Table 5. Detailed work histories of workers who died of lymphosarcoma and reticulosarcoma by pulp process.

\begin{tabular}{|c|c|c|c|}
\hline $\begin{array}{l}\text { Latency } \\
\text { (years) }\end{array}$ & Area or job & $\begin{array}{l}\text { Dates } \\
\text { worked }\end{array}$ & $\begin{array}{c}\text { Age } \\
\text { (years) } \\
\text { at death }\end{array}$ \\
\hline \multicolumn{4}{|c|}{ Sulfate mills } \\
\hline 34 & $\begin{array}{l}\text { Paper machine area } \\
\text { Laboratory }\end{array}$ & $\begin{array}{l}1943-1949 \\
1949-1967\end{array}$ & 71 \\
\hline 31 & Paper machine area & $1935-1966$ & 51 \\
\hline 31 & $\begin{array}{l}\text { Pulp production area } \\
\text { No information on record } \\
\text { Unexposed area }\end{array}$ & $\begin{array}{l}1944-1947 \\
1947-1961 \\
1964-1966 \\
1961-1964\end{array}$ & 74 \\
\hline 26 & $\begin{array}{l}\text { No information on record } \\
\text { Pulp production area }\end{array}$ & $\begin{array}{l}1947-1955 \\
1955-1973\end{array}$ & 63 \\
\hline 22 & $\begin{array}{l}\text { Maintenance/millwright } \\
\text { Leaves of absence }\end{array}$ & $\begin{array}{l}1946-1968 \\
1947,1966\end{array}$ & 62 \\
\hline 13 & Yard labor & $1952-1965$ & 33 \\
\hline \multicolumn{4}{|c|}{ Sulfite mills } \\
\hline 37 & $\begin{array}{l}\text { Raw wood preparation } \\
\text { area } \\
\text { Maintenance }\end{array}$ & $\begin{array}{l}1937-1945 \\
1941 \\
1945-1973\end{array}$ & 63 \\
\hline $\begin{array}{r}16 \\
9\end{array}$ & $\begin{array}{l}\text { Pulp production area } \\
\text { Raw wood preparation } \\
\text { area }\end{array}$ & $\begin{array}{r}1942-1955 \\
1948-1957\end{array}$ & $\begin{array}{l}68 \\
30\end{array}$ \\
\hline 2 & No information on record & $1947-1949$ & 30 \\
\hline
\end{tabular}

entire cohort, were further analyzed by duration of employment and latency. The excess risk of mortality due to lymphosarcoma among the sulfate process workers was the most evident only after 20 years' latency and employment (4 observed, 1.1 expected, SMR 364) (table 8). The stomach cancer risk among the employees of the sulfite pulp mills (table 9) was also the most elevated after a 20 -year latency period (9 observed, 5.1 expected, SMR 176), but during that latency period did not increase with duration of employment.

Among the pulp and paper workers employed over 20 years, excesses of prostate cancer (11 observed, 7.0 expected, SMR 157) and urinary tract cancer ( 9 observed, 5.5 expected, SMR 164) were evident. Among those with greater than 30 years' latency, excesses were seen for prostate cancer (12 observed versus $6.9 \mathrm{ex}$ pected) and urinary tract cancer ( 8 observed versus 4.4 expected). These excesses were independent of process.

Among the subcohort which had worked in production areas with potential formaldehyde exposure, there were 286 deaths, whereas 400.5 were expected (SMR 71). No excess risks of death for any malignancies were found except for urinary tract cancer ( 4 observed versus 1.0 expected, SMR 400) after 30 years' latency. Three of these deaths occurred within the last three years of follow-up. Their detailed work history records showed that all four of the men had worked in the paper-drying areas of the mills for $8,17,25$, and 30 years, respectively. Two had worked in sulfite mills, and the other two had worked in sulfate mills.

\section{Discussion}

The site-specific malignancies with the highest SMR values in this study included lymphosarcoma and re-

Table 6. Selected causes of death among workers in the pulp and paper mills which used the sulfite process. ${ }^{a}$

\begin{tabular}{|c|c|c|c|c|}
\hline Cause of death ${ }^{b}$ & $\begin{array}{l}\text { Observed } \\
\text { deaths }\end{array}$ & $\begin{array}{l}\text { Expected } \\
\text { deaths }\end{array}$ & $\begin{array}{l}\text { Standardized } \\
\text { mortality } \\
\text { ratio }\end{array}$ & $\begin{array}{l}90 \% \\
\text { confidence } \\
\text { limits }\end{array}$ \\
\hline $\begin{array}{l}\text { All causes } \\
\text { All malignant neoplasms }(140-205)\end{array}$ & $\begin{array}{r}523 \\
88\end{array}$ & $\begin{array}{l}605.4 \\
110.7\end{array}$ & $\begin{array}{l}86 \\
79\end{array}$ & $\begin{array}{l}80-93 \\
66-95\end{array}$ \\
\hline $\begin{array}{l}\text { Buccal cavity and pharynx (140-148) } \\
\text { Stomach }(151) \\
\text { Intestines }(152,153) \\
\text { Pancreas }(157) \\
\text { Nasal }(160) \\
\text { Larynx }(161) \\
\text { Lung }(162-163) \\
\text { Prostate (177) } \\
\text { Kidney (180) } \\
\text { Bladder (181) } \\
\text { Lymphosarcoma and reticulosarcoma (200) } \\
\text { Hodgkin's disease (201) } \\
\text { Leukemia (204) } \\
\text { Other lymphoma (202, 203-205) } \\
\text { Residual }\end{array}$ & $\begin{array}{r}-11 \\
5 \\
2 \\
-2 \\
26 \\
9 \\
4 \\
4 \\
4 \\
1 \\
3 \\
1 \\
17\end{array}$ & $\begin{array}{r}3.7 \\
7.4 \\
10.4 \\
6.2 \\
0.3 \\
1.7 \\
32.0 \\
8.1 \\
2.7 \\
3.7 \\
3.0 \\
1.3 \\
4.5 \\
1.5 \\
24.3\end{array}$ & $\begin{array}{r}0 \\
149 \\
48 \\
32 \\
. \\
81 \\
111 \\
148 \\
108 \\
133 \\
\dot{6} \\
\dot{70}\end{array}$ & $\begin{array}{r}0-100 \\
83-246 \\
19-101 \\
6-101 \\
\cdot \\
57-113 \\
58-194 \\
51-339 \\
37-247 \\
45-305 \\
18-172 \\
45-105\end{array}$ \\
\hline Diseases of the blood-forming organs $(290-299)$ & 3 & 1.6 & 188 & $51-486$ \\
\hline
\end{tabular}

a Total person-years 44976 .

b Code of the International Classification of Diseases, seventh revision, in parentheses. 
Table 7. Selected causes of death among workers in the pulp and paper mills which used the Kraft or sulfate processes. ${ }^{a}$

\begin{tabular}{|c|c|c|c|c|}
\hline Cause of death ${ }^{b}$ & $\begin{array}{l}\text { Observed } \\
\text { deaths }\end{array}$ & $\begin{array}{c}\text { Expected } \\
\text { deaths }\end{array}$ & $\begin{array}{l}\text { Standardized } \\
\text { mortality } \\
\text { ratio }\end{array}$ & $\begin{array}{l}90 \% \\
\text { confidence } \\
\text { limits }\end{array}$ \\
\hline All causes & 392 & 544.1 & 72 & $66-78$ \\
\hline All malignant neoplasms (140-205) & 73 & 100.8 & 72 & $59-88$ \\
\hline Buccal cavity and pharynx $(140-148)$ & 1 & 3.4 & 29 & $1-140$ \\
\hline Stomach (151) & 6 & 6.3 & 95 & $42-189$ \\
\hline Intestine $(152,153)$ & 2 & 9.3 & 22 & $4-68$ \\
\hline Pancreas (157) & 2 & 5.6 & 36 & $6-112$ \\
\hline Nasal $(160)$ & - & 0.3 & . & . \\
\hline Larynx (161) & 1 & 1.6 & ${ }^{*}$ & 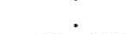 \\
\hline Lung $(162-163)$ & 25 & 30.1 & 83 & $59-215$ \\
\hline Prostate (177) & 8 & 6.7 & 119 & $59-215$ \\
\hline Kidney (180) & 2 & 2.5 & & . \\
\hline Bladder (181) & 4 & 3.2 & 125 & $43-290$ \\
\hline Lymphosarcoma and reticulosarcoma (200) & 6 & 2.9 & 207 & $90-408$ \\
\hline Hodgkin's disease (201) & - & 1.3 & & \\
\hline Leukemia (204) & 1 & 4.2 & 24 & $1-113$ \\
\hline Other lymphoma $(202,203-205)$ & 1 & 1.4 & & \\
\hline Residual & 13 & 22.1 & 59 & $35-94$ \\
\hline
\end{tabular}

Total person-years 46070 .

b Code of the International Classification of Diseases, seventh revision, in parentheses.

Table 8. Observed $(O)$ and expected $(E)$ deaths due to lymphosarcoma by time since first employment and duration of employment among workers in the sulfate process. (SMR $=$ standardized mortality ratio)

\begin{tabular}{|c|c|c|c|c|c|c|}
\hline \multirow{3}{*}{ Latency } & \multicolumn{6}{|c|}{ Duration of employment } \\
\hline & \multicolumn{3}{|c|}{$\begin{array}{l}\text { Less than } \\
20 \text { years }\end{array}$} & \multicolumn{3}{|c|}{$\begin{array}{l}\text { Greater than } \\
20 \text { years }\end{array}$} \\
\hline & 0 & $E$ & SMR & 0 & E & SMR \\
\hline $\begin{array}{l}\text { Less than } 20 \text { years } \\
\text { Greater than } 20 \text { years }\end{array}$ & $\begin{array}{l}1 \\
1\end{array}$ & $\begin{array}{l}0.9 \\
0.8\end{array}$ & $\begin{array}{l}111 \\
125\end{array}$ & $\overline{4}$ & $\begin{array}{l}0 \\
1.1\end{array}$ & 364 \\
\hline
\end{tabular}

Table 9. Observed $(O)$ and expected $(E)$ deaths due to stomach cancer by time since first employment and duration of employment among workers in the sulfite process. (SMR = standardized mortality ratio)

\begin{tabular}{|c|c|c|c|c|c|c|}
\hline \multirow{3}{*}{ Latency } & \multicolumn{6}{|c|}{ Duration of employment } \\
\hline & \multicolumn{3}{|c|}{$\begin{array}{l}\text { Less than } \\
20 \text { years }\end{array}$} & \multicolumn{3}{|c|}{$\begin{array}{l}\text { Greater than } \\
20 \text { years }\end{array}$} \\
\hline & 0 & $E$ & SMR & 0 & $E$ & SMR \\
\hline $\begin{array}{l}\text { Less than } 20 \text { years } \\
\text { Greater than } 20 \text { years }\end{array}$ & $\begin{array}{l}2 \\
4\end{array}$ & $\begin{array}{l}2.3 \\
1.7\end{array}$ & $\begin{array}{r}87 \\
235\end{array}$ & $\overline{5}$ & $\begin{array}{l}0 \\
3.4\end{array}$ & $\dot{147}$ \\
\hline
\end{tabular}

ticulosarcoma and cancer of the stomach and the urinary tract, all of which have been elevated in previous studies of workers in paper-related industries. Although none of these elevated values were statistically significant, this lack of significance could be due to the small numbers of deaths. Both the low background death rates of the causes of death of a priori interest and the small cohort size contributed to the problem of the small numbers of expected deaths for these causes. This problem is reflected in the wide confidence intervals observed for most of the SMR values in table 4 . These intervals allow us to rule out any excess risk of death due to malignancies of the buccal cavity and pharynx, intestines, pancreas, and lung.
Table 10. Detailed work histories of the sulfite mill workers who died of stomach cancer.

\begin{tabular}{rllc}
\hline $\begin{array}{l}\text { Latency } \\
\text { (years) }\end{array}$ & Area or job & $\begin{array}{l}\text { Dates } \\
\text { worked }\end{array}$ & $\begin{array}{c}\text { Age } \\
\text { (years) } \\
\text { at death }\end{array}$ \\
\hline 39 & $\begin{array}{l}\text { Raw wood preparation } \\
\text { No information on record }\end{array}$ & $\begin{array}{l}1929-1932 \\
1932-1942\end{array}$ & 66 \\
& Painter, maintenance & $1942-1945$, & \\
& Groundwood pulp & $1946-1966$ & \\
& production & $1945-1946$ & \\
34 & Groundwood pulp & 1934 & 64 \\
& production & $1940-1956$ & \\
33 & Wood mill, saw mill, yard & $1930-1942$, & 51 \\
& Raw wood preparation & $1946-1955$ & 51 \\
31 & Military leave & $1942-1946$ & \\
24 & Raw wood preparation & $1921-1946$ & 70 \\
& Raw wood preparation & $1938-1956$ & 82 \\
6 & Storekeeper & $1956-1976$ & \\
26 & Yard laborer, watchman & $1944-1949$ & 65 \\
25 & Paper making & $1947-1955$ & 75 \\
32 & Pulp production & $1943-1958$ & 74 \\
9 & Operator, engineer & $1930-1962$ & 59 \\
27 & Fuelman, fireman, power & $1942-1951$ & 60 \\
\hline & Laborer & $1934-1947$ & 75 \\
\hline
\end{tabular}

However, we can only exclude the possibility of SMR values greater than $200-300$ for all other malignancies of any a priori interest from table 1 .

We were surprised by the strikingly low overall SMR of 79 in this group of pulp and paper workers, all of whom entered the cohort at least 22 years before the end of follow-up (table 4). This low SMR does not appear to be due to inadequate follow-up $(1 \%)$. To explore the effect of persons lost to follow-up on the calculation of expected deaths, we carried out an alternative analysis in which person-years at risk were terminated on the day the workers lost to follow-up quit work rather than assuming them to be alive at the end of the study. None of the SMR values calculated by 
this alternative method differed by more than $1 \%$ from those in table 4 .

The cohort did not appear to be diluted by persons with limited duration of exposure or latency. To investigate this possibility, analyses were conducted for both process subcohorts which were stratified by latency and duration of employment. All the SMR values for the long latency and duration of exposure in the all-causes and all-malignant-neoplasms categories were within $5 \%$ of the overall SMR values presented in tables 6 and 7. None of the SMR values was greater than 100 .

The excess risk of death due to lymphosarcoma was greater among the workers in the sulfate process mills (SMR 207) than among those in the sulfite process mills (SMR 133). Among the workers in sulfate process mills, the increased SMR values for lymphosarcoma with long durations of employment and after 20 years since first employment were consistent with an hypothesized occupational etiology. A recent report of provincial mortality (8) based on death-certificate occupation reported statistically significant increased deaths due to lymphosarcoma and reticulosarcoma, as well as to prostate cancer, among Canadian pulp mill workers. However, industrial hygiene information on the work environment and type of pulping process was not reported.

While the excess risk in our study appeared to be restricted to sulfate mills, the lymphosarcoma cases do not seem to cluster in any particular work area. Despite the limitations of the environmental data, it remains noteworthy that many of the lymphosarcoma cases worked in areas with presumable exposure to wood volatiles, which may contain either neoabietic acids (16) or pentachlorophenols used for slime control (14). The latter have been linked to lymphomas by Hardell et al (11). The twofold elevated risk of death from lymphosarcoma among the sulfate workers was independent of the slightly elevated relative risks for lymphosarcoma reported by Milham (21) in a proportionate mortality analysis of pulp mill workers in the same geographic area of the United States. Only three of the ten deaths due to lymphosarcoma or reticulosarcoma in our study cohort were included in his analysis of state vital statistics. Because of the known relationship between immunosuppressive drug therapy and the subsequent development of lymphatic system cancers (16), the nine lymphosarcoma and one reticulosarcoma death certificates were examined for all contributory causes of death. However, no conditions which might require immunosuppressive drug therapy were mentioned on their death certificates.

The elevated SMR for stomach cancer may have been due to life-style factors, which were not controlled in the analyses. Studies have detected an increased incidence among men of lower socioeconomic status. In spite of possible confounding by socioeconomic status, evidence for a possible occupational associa- tion with pulp or paper mill employment is also provided by two other studies $(4,21)$.

The increased risk of dying from stomach cancer among the pulp and paper workers corroborates other studies of workers of such wood-related industries as the furniture, plywood, and sawmill and logging industries $(10,11,20,21,24,25)$, and among carpenters $(20,21)$. According to a recent report, the excess in paper and pulp workers appears to have declined over the last three decades (20). The possibility that these excess risks of stomach cancer are related to wood dusts either directly or indirectly as carriers of carcinogens needs to be evaluated by measurements of particle-size distributions and the modeling of respiratory and digestive system deposition patterns $(5,13)$. Six of the 11 men with stomach cancer in the sulfite/ groundwood workers' subcohort had worked in areas of wood preparation (table 10), where log debarking and chipping into small pieces takes place (tables 2 and 10 ).

The fourfold excess of urinary tract cancer after 30 years' latency among those who worked in paperdrying areas with potential exposure to formaldehyde appears to warrant further investigation. Although at least one mill was believed to have used benzidenebased dyes, known urinary tract carcinogens, no exposure data were available at the mills. Levels of up to $2.5 \mathrm{ppm}$ of formaldehyde (Stanford Research Institute project no 5847 report) have been found in these pulp mills. It is noteworthy that an excess risk of kidney cancer (a proportional mortality ratio of 256 , based on 6 cases) has been reported among embalmers exposed to formaldehyde (30).

Two $(2,4)$ of several epidemiologic studies of pulp and paper mill workers have reported excess risks for dying of cancer of the buccal cavity, but a large deficit (1 observed, 6.6. expected) was observed in our study. A fourfold relative risk for oral and laryngeal cancer was observed by DeCoufle et al (4) among men who had worked as operatives in the paper industry for five years or more. In addition a significantly increased mortality rate for oral cancer was observed among white males by Blot \& Fraumeni (2) for US counties with more than $1 \%$ of the population employed in the paper industry.

The elevated rates we observed for lymphosarcoma, stomach cancer, and urinary tract cancer, while not statistically significant, were provocative because of the associations observed in earlier epidemiologic studies. These excesses do not appear to be due to differences between local and US mortality rates. In Washington State, where the mills are located, the mortality rates for lymphosarcoma, other lymphomas and mycosis fungoides; bladder cancer; and stomach cancer are all within $1 \%$ of the respective US mortality rates (17).

A deficit of risk due to lung cancer was observed in this study (50 observed, 62.1 expected, SMR 81). Lung cancer has been associated with pulp and paper 
mill employment in some studies $(1,12,19)$ but not in others $(3,9)$. In the only study which considered cigarette smoking, a case-referent study of 535 male residents of coastal Georgia, no association was found with pulp or paper mills (3).

\section{Conclusion}

Statistically nonsignificant excesses of mortality due to lympho- and reticulosarcoma and stomach cancer were found in a cohort of pulp and paper mill workers. These findings tend to corroborate reports based on state vital statistics, as well as preliminary studies of pulp or paper mill workers which observed associations with lymphatic cancer. In our study, the lymphosarcoma excess was restricted to those who had worked in the sulfate mills, while the stomach cancer excess was limited to those who had worked in the sulfite mills. These process-specific SMR values were highest after 20 years since first employment in the mills. Although no etiologic agents were distinguishable, further research, including the continuing followup of this cohort and the characterization of exposureresponse relationships, should be conducted. Future research should focus on the potential carcinogenic roles of exposure to wood dust, formaldehyde, sulfur compounds, and other chemicals in this industry.

\section{Acknowledgments}

The authors thank the pulp and paper mills and unions which participated in the study and the tripartite committee members. We thank Dr G Marsh for his biostatistical review, Dr S Milham, Jr, for his assistance with the death certificates and other aspects, and $\mathrm{Dr}$ JK Wagoner and Mr RA Lemen, who helped initiate the study. We acknowledge Dr W Gaffey for his contribution during the plant identification, data collection, and data reduction and the assistance of Ms A Winship-Ball and $J$ Cohen at the Stanford Research Institute. We thank Mr P Bierbaum, Mr D Brown, and other NIOSH personnel who worked on the study, and the Southwestern Ohio Regional Computer Center, which assisted with the data reduction and analysis.

\section{References}

1. Blot WJ, Fraumeni JF Jr. Geographic patterns of lung cancer: Industrial correlations. Am J Epidemiol 103 (1976) 539-550.

2. Blot WJ, Fraumeni JF Jr. Geographic patterns of oral cancer in United States: Etiologic implications. J Chronic Dis 30 (1977) $745-757$.

3. Blot WJ, Harrington JM, Toledo A, Hoover R, Heath CW Jr, Fraumeni JF Jr. Lung cancer after employment in shipyards during World War II. New Engl J Med 299 (1978) 620-624.

4. Decoufle P, Stanislawczyk K, Houten L, Bross IDJ, Viadana E. Retrospective survey of cancer in relation to occupation. US Government Printing Office, Washington, DC 1977. (DHEW (NIOSH) publication no
77-178: 146).

5. Dement JL, Harris RL. Estimates of pulmonary and gastrointestinal deposition for occupational fiber exposures. US Government Printing Office, Washington, DC 1979. (DHEW (NIOSH) publication no 79-135).

6. Ferris BG Jr, Puleo S, Chen HY. Mortality and morbidity in a pulp and a paper mill in the United States: A ten year follow-up. Br J Ind Med 36 (1979) 127-134.

7. Forest Products Laboratory. Woodpulp mills in the United States. Forest Service, US Department of Agriculture, Washington, DC 1977. (USDA forest service resource report FPL-1).

8. Gallagher RP, Threlfall WJ. Cancer risk in wood and pulp workers. In: Stitch H, ed. Carcinogens and mutagens in the environment. Volume 5. CRC Press Inc, Boco Raton, FL 1985.

9. Gottlieb MS, Pickle LW, Blot WJ, Fraumeni JF Jr. Lung cancer in Louisiana: Death certificate analysis. $\mathrm{J}$ Natl Cancer Inst 63 (1979) 1131-1137.

10. Guralnick L. Mortality by industry and cause of death. Vital Stat Spec Rep 53 (1963): 4, 369-370.

11. Hardell L, Eriksson M, Lenner P, Lundgren E. Malignant lymphoma and exposure to chemicals, especially organic solvents, chlorophenols and phenoxy acids, a case control study. Br J Cancer 43 (1981) 169-176.

12. Harrington JM, Blot WJ, Hoover RN, Housworth WJ, Heath CA, Fraumeni JF Jr. Lung cancer in coastal Georgia: A death certificate analysis of occupation. J Natl Cancer Inst 60 (1978) 295-298. (Brief communication).

13. Harris JRL. Aerodynamic considerations; what is a respirable fiber of fibrous glass? In: US Government Printing Office. Proceedings, NIOSH Symposium on Occupational Exposures to Fibrous Glass. Washington, DC 1974. (DHEW (NIOSH) publication no 76-151).

14. International Agency for Research on Cancer. Wood, leather and some associated industries. Lyon 1981. (IARC monographs on evaluation of the carcinogenic risk of chemicals to humans, volume 25 ).

15. International Agency for Research on Cancer. Some industrial chemicals and dyestuffs. Lyon 1982. (IARC monographs on the evaluation of the carcinogenic risk of chemicals to humans, volume 29).

16. International Agency for Research on Cancer. Some antineoplastic and immunosuppressive agents. Lyon 1981. (IARC monographs on the evaluation of the carcinogenic risk of chemicals to humans, volume 26).

17. Mason TJ, McKay FW. US cancer by county: 19501969. US Government Printing Office, Washington, DC 1979. (DHEW publication no (NIH) 79-1649).

18. McDonald RG, ed. Pulp and paper manufacture. Volumes I, II, III. McGraw Hill Book Company, New York, NY 1969.

19. Menck HR, Henderson BE. Occupational differences in rates of lung cancer. J Occup Med 18 (1976) 797-801.

20. Milham S Jr. Occupational mortality in Washington State 1950-1979. US Government Printing Office, Washington, DC 1983. (DHHS (NIOSH) publication no 83-116).

21. Milham S Jr. Occupational mortality in Washington State 1950-1971. US Government Printing Office, Washington, DC 1976. (DHEW (NIOSH) publication no $76-175 \mathrm{~A}, \mathrm{~B}, \mathrm{C})$.

22. Milham S Jr, Hesser JE. Hodgkin's disease in woodworkers. Lancet 2 (1967) 136-137.

23. Office of Population Censuses and Surveys. Occupational mortality: The Registrar General's decennial supplement for England and Wales 1970-72. Her Majesty's Stationery Office, London 1978.

24. Registrar General. Decennial supplement, England and Wales, 1951: Occupational mortality, part II, Volume 1 (Commentary). Her Majesty's Stationery Office, London 1958.

25. Registrar General. Decennial supplement, England and 
Wales, 1951: Occupational mortality, part II. Volume 2 (Tables). Her Majesty's Stationery Office, London 1958.

26. Registrar General. Decennial supplement, England and Wales, 1961: Occupational mortality, tables. Her Majesty's Stationery Office, London 1971.

27. Rothman KJ, Boice JD Jr. Epidemiologic analysis with a programmable calculator. US Government Printing Office, Washington, DC 1979. (NIH publication no 79-1649).

28. US Bureau of the Census. Statistical abstract of the US. Washington, DC 1977, p 801.

29. US Department of Health, Education and Welfare. Vital statistics of the US 1970 . Volume II, Part A. Hyattsville, MD 1973.

30. Walrath J, Fraumeni JF Jr. Proportionate mortality among New York embalmers. In: Proceedings of the third annual conference "Formaldehyde Toxicity," Hemisphere Publishing Corp, New York, NY (in press).

31. Waxweiler RJ, Beaumont JJ, Henry JA, Brown DP, Robinson CF, Ness GO, Wagoner JK, Lemen RA. A modified life table analysis system for cohort studies. J Occup Med 25 (1983) 2, 115-124.

Received for publication: 26 June 1986 